\title{
PENGARUH BERBAGAI TINGKAT FRAKSI EKSTRAK DAUN MENGKUDU (Morinda citrifolia L) TERHADAP PERTUMBUHAN Colletotrichum capsici PENYEBAB PENYAKIT ANTRAKNOSA PADA CABAI (Capsicum annum L) SECARA IN VITRO
}

\author{
Septya Eka Prasetia Rani, Efri \& Joko Prasetyo \\ Jurusan Agroteknologi, Fakultas Pertanian, Universitas Lampung \\ J1. Soemantri Brodjonegoro No. 1 Bandar Lampung 35145
}

\begin{abstract}
ABSTRAK
Penelitian ini bertujuan untuk mempelajari pengaruh berbagai fraksi ekstrak daun mengkudu terhadap pertumbuhan dan perkembangan Colletotrichum capsici penyebab penyakit antraknosa pada cabai secara in vitro. Hasil analisis data menunjukkan bahwa perlakuan ekstrak daun mengkudu yang terlarut dalam alkohol konsentrasi 10\%, 30\%, 50\%, 60\%, 70\%, $90 \%$ dan ekstrak daun mengkudu yang terlarut dalam aquades efektif menghambat pertumbuhan diameter pada koloni $C$. Capsici. Selain menghambat pertumbuhan vegetatif, ekstrak daun mengkudu yang terlarut dalam alkohol konsentrasi $10 \%$ dan $30 \%$ juga menghambat pembentukan spora (sporulasi) koloni $C$. capsici.
\end{abstract}

Kata kunci : ekstrak daun mengkudu, Colletotrichum capsici.

\section{PENDAHULUAN}

Cabai merupakan komoditas sayuran yang tidak dapat ditinggalkan masyarakat dalam kehidupan seharihari.Selain berguna sebagai penyedap masakan dan pembangkit selera makan, cabai juga mengandung zatzat gizi yang sangat diperlukan untuk kesehatan manusia.Cabai mengandung protein, lemak, karbohidrat, kalsium, fosfor, besi, vitamin-vitamin, dan mengandung senyawa alkaloid, seperti capsaicin, flavonoid, dan minyak esensial (Prajnanta, 2003).Beberapa tahun terakhir ini, cabai menempati urutan yang paling atas diantara 18 jenis sayuran komersial yang dibudidayakan di Indonesia.Meskipun harga pasar cabai sering naik dan turun cukup tajam, minat petani tidak pernah surut (Rukmana, 2009).

Di Propinsi Lampung, cabai merah termasuk salah satu komoditi tanaman sayuran unggulan . Komoditi tersebut banyak diusahakan di lahan kering baik dataran tinggi maupun dataran rendah. Propinsi Lampung mempunyai potensi sumberdaya alam khususnya lahan kering yang sesuai untuk pengembangan tanaman pangan dan hortikultura (BPTP Lampung, 2008). Menurut Badan Pusat Statistik (2011) luas panen cabai di Lampung tahun 2010 mencapai 8.424 hektar, dengan produksi mencapai 35.360 ton dan produktivitas rata-rata ditingkat petani 4,58 ton/hektar. Hasil ini masih termasuk rendah jika dibandingkan dengan rata-rata produktivitas nasional yang mencapai 5,60 ton ha ${ }^{-1}$.

Penyebab rendahnya produksi cabai antara lain adalah serangan hama dan penyakit. Beberapa penyakit dapat menyerang tanaman cabai, akan tetapi penyakit yang sangat penting dan penyebarannya sangat luas adalah penyakit antraknosa. Penyakit antraknosa disebabkan oleh Colletotrichum capsici (Syd.) Butl. et Bisby, dapat ditemukan pada daun dan batang dan selanjutnya menginfeksi buah (Semangun, 2004). Selain dipertanaman penyakit antraknosa juga terdapat dipenyimpanan (Setiadi, 2000).Penyakit antraknosa sangat ditakuti karena dapat menghancurkan seluruh pertanaman. Cabai segar yang disimpan 1-2 hari sebelum dipasarkan pun dapat memperlihatkan gejala serangan penyakit ini karena antraknosa dapat terbawa, tumbuh, dan bertahan di dalam biji selama sembilan bulan (Prajnanta, 2003). Penyakit ini juga banyak terdapat di daerah transmigrasi Lampung, dan dianggap sebagai penyakit yang merugikan (Semangun, 2004).

Pada umumnya penyakit antraknosa dikendalikan secara kimiawi, menggunakan fungisida sintetik yang banyak digunakan adalah fungisida sistemik berbahan aktif triadianefon dicampur dengan fungisida kontak berbahan aktif tembaga hidroksida seperti Kocide 54WDG, atau yang berbahan aktif Mankozeb seperti Victory 80WP (Departemen Pertanian, 2011). Namun demikian, penggunaan fungisida sintetik dapat 
menimbulkan dampak buruk bagi lingkungan sekitar seperti terbunuhnya organisme non target, membahayakan kesehatan operator dan lingkungan, serta memerlukan biaya yang cukup besar.Salah satu alternatif pengendalian yang aman adalah menggunakan pestisida nabati. Penggunaan pestisida nabati selain dapat mengurangi pencemaran lingkungan, harganya relatif murah apabila dibandingkan dengan pestisida sintetis. Pestisida nabati dapat dibuat secara sederhana berupa larutan hasil perasan, rendaman, ekstrak, dan rebusan bagian tanaman, yaitu berupa akar, umbi, batang, daun, biji, dan buah (Sudarmo, 2009).

Tanaman mengkudu merupakan salah satu tanaman yang berpotensi sebagai pestisida nabati. Menurut Waha (2001) mengkudu mengandung acubin, L. asperuloside, alizarin dan beberapa zat antraquinon telah terbukti sebagai zat anti bakteri. Zat-zat yang terdapat di dalam buah mengkudu telah terbukti menunjukkan dapat menekan pertumbuhan jamur-jamur tertentu.Menurut Ogundare dan Onifade (2009) ekstrak daun mengkudu pada konsentrasi $25 \mathrm{mg} \mathrm{ml}^{-1}$ mampu menghambat pertumbuhan Escherichia coli dengan zona penghambatan $5 \mathrm{~mm}$. Namun bagian efektif terhadap jamur C. capsici masih perlu diteliti. Efektifitas ekstrak daun mengkudu dapat ditingkatkan dengan cara fraksinasi yaitu memisahkan senyawa-senyawa yang terkandung dalam ekstrak dengan cara ekstraksi bertingkat menggunakan konsentrasi pelarut yang berbeda.

\section{METODE PENELITIAN}

Perlakuan dalam percobaan ini disusun dalam rancangan acak lengkap (RAL) dengan sebelas perlakuan dan tiga ulangan. Perlakuan terdiri atas kontrol (K), ekstrak daun mengkudu yang terlarut dalam alkohol konsentrasi $10 \%(\mathrm{DM}+10), 20 \%(\mathrm{DM}+20), 30 \%$ $(\mathrm{DM}+30), 40 \%(\mathrm{DM}+40), 50 \%(\mathrm{DM}+50), 60 \%$ $(\mathrm{DM}+60), 70 \%(\mathrm{DM}+70), 80 \%(\mathrm{DM}+80)$, dan $90 \%$ $(\mathrm{DM}+90)$, serta ekstrak daun mengkudu yang terlarut dalam aquades $(\mathrm{DM}+\mathrm{Aq})$. Data hasil pengamatan dianalisis menggunakan sidik ragam dan perbedaan nilai tengah antar perlakuan diuji dengan Uji Jarak Berganda (Duncan) pada taraf nyata 5\%. Langkah-langkah dalam pelaksanaan penelitian ini yaitu sebagai berikut :

Penyiapan Isolat. $C$. capsici diisolasi dari buah cabai yang menunjukkan gejala busuk atau terinfeksi. Jaringan kulit buah yang bergejala dipotong pada bagian perbatasan antara bagian yang sakit dan yang sehat $( \pm$ $5 \mathrm{~mm}$ ), kemudian potongan direndam dalam larutan $\mathrm{NaOCl} 1 \%$ selama 2 menit, dan dibilas dengan aquades steril. Selanjutnya potongan kulit buah tersebut ditanam dalam cawan petri yang berisi media PDA dan diinkubasi dalam suhu ruang selama 3 hari.Jamur yang tumbuh kemudian isolasi dan diidentifikikasi.

Pembuatan Ekstrak Daun Mengkudu. Daun mengkudu diperoleh dari tanaman mengkudu di sekitar lingkungan Fakultas Pertanian, Universitas Lampung.Daun mengkudu yang digunakan adalah daun yang tidak terlalu muda dan tidak terlalu tua yaitu pada ruas ke 4 - 5 dari pucuk daun.Daun mengkudu seberat 100 gram dicuci dengan air bersih lalu dikering-anginkan. Kemudian daun mengkudu dipotong-potong dan diblender dengan diberi sedikit air untuk memperoleh bentuk yang lebih halus, selanjutnya dilarutkan dan diekstrak berturut-turut dengan 1 liter aquades, $10 \%$, $20 \%, 30 \%, 40 \%, 50 \%, 60 \%, 70 \%, 80 \%$, dan $90 \%$ menggunakan alat yang dirancang menggunakan paralon. Alat yang digunakan untuk mengekstrak dibuat dengan menggunakan paralon berbagai ukuran yang terdiri atas empat sambungan dan setiap sambungannya diberi kain kasa.Pada sambungan kedua diisi arang aktif yang telah dihaluskan sebagai filter.Masing-masing larutan hasil ekstraksi selanjutnya dituang dalam nampan plastik dan diuapkan dalam ruangan dengan suhu kamar, sehingga diperoleh fraksi kering ekstrak daun mengkudu dan disimpan dalam lemari es untuk pengujian selanjutnya.

Penyiapan Media Tumbuh Jamur C. capsici untuk Perlakuan Pengujian. Pembuatan media PDA dimulai dengan 250 gr kentang dipotong kecil - kecil, lalu direbus didalam $1250 \mathrm{ml}$ air sambil diaduk, setelah itu rebusan kentang disaring dan dimasukkan kedalam dua labu erlenmeyer masing - masing berukuran 1 liter dan 250 $\mathrm{ml}$ yang sebelumnya telah diberi 20 gr gula dan $20 \mathrm{gr}$ agar pada labu erlenmeyer 1 liter dan 5 gr gula dan 5 gr agar pada labu erlenmeyer $250 \mathrm{ml}$. Media dalam labu erlenmeyer tersebut disterilisasi di dalam otoklaf. Setelah proses sterilisasi selesai, media PDA $1250 \mathrm{ml}$ tadi dibagi kedalam 11 labu erlenmeyer yang berbeda, masing - masing menjadi $100 \mathrm{ml}$ larutan PDA. Tiap tabung yang telah berisi $100 \mathrm{ml}$ PDA dicampur dengan $10 \mathrm{mg}$ masing-masing fraksi kering ekstrak daun mengkudu.

Uji Penghambatan Pertumbuhan. Uji penghambatan pertumbuhan $C$. capsicidilakukan untuk mengetahui ukuran diameter koloni pada tiap-tiap perlakuan pada media PDA dalam cawan petri. Masing - masingfraksi kering ekstrak daun mengkudu dicampurkan dalam media PDA dengan konsentrasi 100 ppm yaitu $10 \mathrm{mg}$ 
bagian fraksi kering ekstrak daun mengkudu per $100 \mathrm{ml}$ bagian media PDA dan di tuang kedalam cawan petri. Jamur $C$. capsici yang telah dimurnikan diambil dengan bor gabus yang berukuran $\pm 5 \mathrm{~mm}$ dan diletakkan pada bagian tengah cawan petri. Masing - masing perlakuan dilakukan tiga kali ulangan.Pengamatan dilakukan terhadap diameter koloni jamur sehingga diketahui kemampuan dari masing - masing fraksi ekstrak daun mengkudu dalam menghambat pertumbuhan $C$. capsici.Pengamatan ini dilakukan pada hari ke-2 hingga hari ke-11 setelah infestasi. Data pertumbuhan koloni jamur yang didapat merupakan rata - rata empat kali pengukuran diameter pada daerah yang berbeda.

Data yang diperoleh selanjutnya digunakan untuk menghitung persentase penghambatan ekstrak daun mengkudu terhadap $C$. capsici dengan rumus sebagai berikut (Ahmad dan Suryana, 2009).

$$
P=\frac{D 1-D 2}{D 1} \times 100 \%
$$

dengan $\mathrm{P}$ adalah persentase penghambatan, D1 adalah diameter C.capsici. pada kontrol (cm), dan D2 adalah diameter $C$. capsici. pada setiap perlakuan (cm).

\section{Pengamatan dan Penghitungan Jumlah Spora.}

Pengamatan dilakukan untuk mengetahui jumlah spora pada tiap-tiap perlakuan. Pengamatan ini diperlukan sebagai data pendukung dari data pengamatan pertumbuhan $C$. capsici.Jumlah spora dihitung menggunakan metode hitungan mikroskopis langsung, dimana sampel diletakkan pada haemocytometer.
Jumlah spora dapat dihitung dengan cara mengambil semua spora yang tumbuh pada tiap cawan petri dalam tiap ulangan. Suspensi spora C. capsici kemudian dimasukkan ke dalam $10 \mathrm{ml}$ aquades steril di dalam cawan petri setelah itu dihomogenkan.Selanjutnya suspensi spora $C$. capsici diteteskan pada ruang hitung haemocytometerdan ditutup dengan kaca obyek, sehingga suspensi mengalir ke bawah kaca obyek mengisi ruang hitung. Lalu jumlah spora dihitung dalam lima kotak sedang di bawah mikroskop dan dilihat rataratanya.Jumlah spora dihitung dengan rumus menurut Sudibyo (1994) dalam Surtikant dan Juniarsih (2010):

$\mathrm{K}=$ Jumlah spora $\mathrm{x} 2,5 \times 10^{6}$

dengan $\mathrm{K}$ adalah kerapatan spora per ml dan 2,5 x $10^{6}$ adalah konstanta atau faktor koreksi penggunaan kotak sampel pada haemocytometer. Uji kerapatan ini dilakukan sebanyak tiga ulangan dari setiap perlakuan.

\section{HASIL DAN PEMBAHASAN}

\begin{abstract}
Pengaruh Ekstrak Daun Mengkudu Terhadap Pertumbuhan Diameter C.Capsici. Aktivitas antifungi ekstrak daun mengkudu ditentukan dengan mengukur pertumbuhan koloni jamur $C$. capsici, yaitu semakin kecil ukuran diameter koloni jamur $C$. capsici maka semakin besar pengaruh ekstrak daun mengkudu terhadap pertumbuhan jamur C. capsici. Dari hasil analisis data terlihat bahwa perlakuan ekstrak daun mengkudu memiliki pengaruh terhadap pertumbuhan koloni jamur C. capsici (Tabel 1). Namun demikian
\end{abstract}

Tabel 1. Ukuran diameter koloniC. capsicisetelah perlakuan dengan daun mengkudu

\begin{tabular}{lllllllllll}
\hline \multirow{2}{*}{ Perlakuan } & \multicolumn{7}{c}{ Diameter koloni $(\mathrm{cm})$} \\
\cline { 2 - 10 } & 2hsi & $3 \mathrm{hsi}$ & $4 \mathrm{hsi}$ & $5 \mathrm{hsi}$ & $6 \mathrm{his}$ & $7 \mathrm{hsi}$ & $8 \mathrm{hsi}$ & $9 \mathrm{his}$ & $10 \mathrm{hsi}$ & $11 \mathrm{his}$ \\
\hline Kontrol & $1,21 \mathrm{a}$ & $1,89 \mathrm{a}$ & $2,75 \mathrm{a}$ & $3,42 \mathrm{a}$ & $4,20 \mathrm{a}$ & $5,03 \mathrm{a}$ & $5,71 \mathrm{a}$ & $6,18 \mathrm{a}$ & $6,53 \mathrm{a}$ & $7,05 \mathrm{a}$ \\
D.M+Aq & $1,05 \mathrm{abc}$ & $1,77 \mathrm{a}$ & $2,38 \mathrm{~b}$ & $2,90 \mathrm{c}$ & $3,23 \mathrm{c}$ & $3,78 \mathrm{~b}$ & $4,32 \mathrm{bc}$ & $4,57 \mathrm{a}$ & $4,86 \mathrm{bcd}$ & $5,22 \mathrm{bcd}$ \\
D.M+10 & $0.74 \mathrm{~d}$ & $1,42 \mathrm{~b}$ & $1,85 \mathrm{c}$ & $2,44 \mathrm{~d}$ & $3,08 \mathrm{~cd}$ & $3,75 \mathrm{~b}$ & $4,41 \mathrm{bc}$ & $4,60 \mathrm{bcd}$ & $5,13 \mathrm{abcd}$ & $5,13 \mathrm{bcd}$ \\
D.M+20 & $1,10 \mathrm{ab}$ & $1,83 \mathrm{a}$ & $2,32 \mathrm{~b}$ & $3,38 \mathrm{a}$ & $4,13 \mathrm{ab}$ & $4,87 \mathrm{a}$ & $5,38 \mathrm{ab}$ & $5,83 \mathrm{abc}$ & $6,04 \mathrm{abc}$ & $6,08 \mathrm{abc}$ \\
D.M+30 & $0,78 \mathrm{~d}$ & $1,17 \mathrm{~b}$ & $1,58 \mathrm{c}$ & $1,95 \mathrm{~d}$ & $2,13 \mathrm{~d}$ & $2,38 \mathrm{~b}$ & $2,40 \mathrm{~d}$ & $2,42 \mathrm{~d}$ & $2,45 \mathrm{~d}$ & $2,56 \mathrm{~d}$ \\
D.M+40 & $0,93 \mathrm{bc}$ & $1,29 \mathrm{~b}$ & $1,91 \mathrm{c}$ & $2,54 \mathrm{~cd}$ & $3,07 \mathrm{~cd}$ & $3,69 \mathrm{~b}$ & $4,20 \mathrm{~cd}$ & $4,48 \mathrm{~cd}$ & $4,98 \mathrm{abc}$ & $5,34 \mathrm{abcd}$ \\
D.M+50 & $0,87 \mathrm{~cd}$ & $1,30 \mathrm{~b}$ & $1,80 \mathrm{c}$ & $2,36 \mathrm{~d}$ & $2,77 \mathrm{~d}$ & $3,30 \mathrm{~b}$ & $3,66 \mathrm{~cd}$ & $3,81 \mathrm{~d}$ & $4,23 \mathrm{~d}$ & $4,23 \mathrm{~d}$ \\
D.M+60 & $0,99 \mathrm{bc}$ & $1,41 \mathrm{~b}$ & $1,93 \mathrm{c}$ & $2,58 \mathrm{~cd}$ & $3,08 \mathrm{~cd}$ & $3,58 \mathrm{~b}$ & $4,00 \mathrm{~cd}$ & $4,41 \mathrm{~d}$ & $4,75 \mathrm{~cd}$ & $5,16 \mathrm{bcd}$ \\
D.M+70 & $0,88 \mathrm{~cd}$ & $1,30 \mathrm{~b}$ & $1,82 \mathrm{c}$ & $2,28 \mathrm{~d}$ & $2,78 \mathrm{~d}$ & $3,23 \mathrm{~b}$ & $3,30 \mathrm{~d}$ & $3,41 \mathrm{~d}$ & $3,58 \mathrm{~d}$ & $3,80 \mathrm{~d}$ \\
D.M+80 & $1,05 \mathrm{abc}$ & $1,76 \mathrm{a}$ & $2,54 \mathrm{ab}$ & $3,33 \mathrm{ab}$ & $4,15 \mathrm{a}$ & $4,97 \mathrm{a}$ & $5,33 \mathrm{ab}$ & $5,92 \mathrm{ab}$ & $6,39 \mathrm{ab}$ & $6,75 \mathrm{ab}$ \\
D.M+90 & $1,05 \mathrm{abc}$ & $1,72 \mathrm{a}$ & $2,36 \mathrm{~b}$ & $2,94 \mathrm{bc}$ & $3,49 \mathrm{bc}$ & $3,79 \mathrm{a}$ & $4,00 \mathrm{~cd}$ & $4,19 \mathrm{~d}$ & $4,52 \mathrm{~d}$ & $4,73 \mathrm{~cd}$ \\
\hline F-Hitung & $3,75^{*}$ & $6,44^{*}$ & $10,74^{*}$ & $10,93^{*}$ & $8,30^{*}$ & $8,21^{*}$ & $6,58^{*}$ & $5,50^{*}$ & $4,77 *$ & $4,67^{*}$ \\
\hline
\end{tabular}

Nilai dalam kolom yang diikuti huruf yang sama, tidak berbeda nyata menurut uji Duncan $\alpha_{0,05}$. Hsi: hari setelah infestasi. Kontrol: media PDA tanpa perlakuan. 
pengaruh perlakuan berbeda pada masing-masing fraksi. Hal ini mengindikasikan bahwa perlakuan fraksinasi dapat mengakibatkan pemisahan bahan-bahan aktif yang terkandung dalam daun mengkudu yang mempunyai pengaruh yang berbeda-beda.

Berdasarkan hasil analisis data perlakuan ekstrak mengkudu yang terlarut dalam alkohol konsentrasi $10 \%$, $30 \%, 50 \%, 60 \%, 70 \%, 90 \%$ dan ekstrak daun mengkudu yang terlarut dalam aquades, efektif memberikan pengaruh penghambatan diameter pada koloni $C$. capsici. Hasil analisis data di atas diperkuat berdasarkan hasil analisis parameter persentase penghambatan.Pada hari kedua hingga hari kesebelas perlakuan D.M+30 dan D.M+70memiliki persentase penghambatan tertinggi (Tabel 2).

Pertumbuhan $C$. capsici pada media PDA yang mengandung ekstrak daun mengkudu dapat terhambat diduga karena pengaruh senyawa alkaloid.Dugaan ini berdasarkan laporan dari Solomon dan Graham (1980) dalam Pratomo (2012), yang menyatakan bahwa senyawa-senyawa yang tergolong dalam alkaloid memiliki sifat antimikroba yang dapat menghambat pertumbuhan beberapa jamur.Komponen kimia senyawa alkaloid yang bersifat antifungal mampu menembus dinding sel jamur. Dengan demikian akan terjadi gangguan proses metabolisme di dalam sel sehingga akan mengganggu pertumbuhan sel, dan pada konsentrasi tertentu akan berakibat kematian sel jamur (Knobloch et al., 1989 dalam Nurmansyah, 2010).
Adanya hambatan dari ekstrak daun mengkudu terhadap pertumbuhan jamur $C$. capsici dapat disebabkan adanya senyawa-senyawa aktif yang terkandung di dalamekstrak daun mengkudu yaitu senyawa alkaloid seperti antraquinon, glikosida, resin (Djauhariya et al., 2006) yang mempunyai sifat antifungi maupun antimikroba. Zat-zat yang terdapat di dalam daun mengkudu telah terbukti menunjukkan kekuatan melawan golongan bakteri infeksi: Pseudomonas aeruginosa, Proteus morganii, Staphylococcus aureus, Bacillus subtilis dan Escherichia coli. Selain itu, mengkudu juga memiliki kandungan zat kimia yang mempunyai efek antifungi dan antibiotik, yaitu Scopoletin sebagai anti jamur, Antraquinone untuk melawan infeksi bakteri dan jamur, Terpenes sebagai bioflavanoid dan karotenoid yang berfungsi sebagai zat anti infeksi fungi dan bakteri, dan Xeronine anti infeksi jamur (Puspita dan Andriani, 2005).

\section{Pengaruh Ekstrak Daun Mengkudu terhadap Jumlah Spora. Berdasarkan hasil analisis data menunjukkan bahwa perlakuan yang diberi ekstrak mengkudu memiliki pengaruh terhadap jumlah spora jamur C. capsici. Pada perlakuan D.M+10 dan DM+30 mempunyai jumlah spora paling sedikit dibandingkan dengan kontrol dan perlakuan lain (Tabel 3). Berdasarkan analisis ragam tersebut ekstrak daun mengkudu pada perlakuan $\mathrm{DM}+10$ dan $\mathrm{DM}+30$ dapat menghambat pembentukan spora jamur $C$. capsici.}

Tabel 2. Persentase penghambatan ekstrak daun mengkudu terhadap pertumbuhan C. capsici

\begin{tabular}{crrrrrrrrrr}
\hline \multirow{2}{*}{ Perlakuan } & \multicolumn{10}{c}{ Persentase penghambatan $(\%)$} \\
\cline { 2 - 10 } & 2 hsi & \multicolumn{1}{c}{3 hsi } & \multicolumn{1}{c}{4 hsi } & 5 hsi & \multicolumn{1}{c}{6 hsi } & 7 hsi & 8 hsi & 9 hsi & 10 hsi & 11 hsi \\
\hline Kontrol & 0,00 & $0,00 \mathrm{~b}$ & $0,00 \mathrm{~b}$ & $0,00 \mathrm{c}$ & $0,00 \mathrm{a}$ & $0,00 \mathrm{c}$ & $0,00 \mathrm{c}$ & $0,00 \mathrm{c}$ & $0,00 \mathrm{c}$ & $0,00 \mathrm{c}$ \\
D.M+Aq & 8,75 & $5,21 \mathrm{~b}$ & $12,03 \mathrm{~b}$ & $14,11 \mathrm{~b}$ & $22,90 \mathrm{~b}$ & $24,69 \mathrm{~b}$ & $24,47 \mathrm{~b}$ & $26,34 \mathrm{~b}$ & $25,92 \mathrm{~b}$ & $26,26 \mathrm{~b}$ \\
D.M+10 & 37,41 & $25,59 \mathrm{a}$ & $32,51 \mathrm{a}$ & $28,39 \mathrm{a}$ & $26,94 \mathrm{~b}$ & $25,58 \mathrm{~b}$ & $22,90 \mathrm{~b}$ & $25,40 \mathrm{~b}$ & $21,19 \mathrm{~b}$ & $26,57 \mathrm{~b}$ \\
D.M+20 & 3,84 & $2,00 \mathrm{~b}$ & $14,95 \mathrm{~b}$ & $0,14 \mathrm{c}$ & $1,26 \mathrm{c}$ & $3,17 \mathrm{c}$ & $5,62 \mathrm{c}$ & $5,72 \mathrm{c}$ & $7,42 \mathrm{c}$ & $14,00 \mathrm{c}$ \\
D.M+30 & 33,95 & $37,75 \mathrm{a}$ & $42,23 \mathrm{a}$ & $42,60 \mathrm{a}$ & $49,20 \mathrm{a}$ & $52,73 \mathrm{a}$ & $58,30 \mathrm{a}$ & $61,51 \mathrm{a}$ & $63,01 \mathrm{a}$ & $64,36 \mathrm{a}$ \\
D.M+40 & 21,95 & $31,53 \mathrm{a}$ & $30,21 \mathrm{a}$ & $25,31 \mathrm{a}$ & $27,09 \mathrm{~b}$ & $26,65 \mathrm{~b}$ & $26,61 \mathrm{~b}$ & $27,75 \mathrm{~b}$ & $24,26 \mathrm{~b}$ & $24,67 \mathrm{~b}$ \\
D.M+50 & 26,09 & $50,53 \mathrm{a}$ & $34,03 \mathrm{a}$ & $30,45 \mathrm{a}$ & $34,29 \mathrm{a}$ & $34,68 \mathrm{~b}$ & $36,48 \mathrm{~b}$ & $39,29 \mathrm{~b}$ & $36,37 \mathrm{~b}$ & $41,11 \mathrm{~b}$ \\
D.M+60 & 15,17 & $24,66 \mathrm{a}$ & $29,07 \mathrm{a}$ & $23,91 \mathrm{~b}$ & $26,62 \mathrm{~b}$ & $28,55 \mathrm{~b}$ & $29,48 \mathrm{~b}$ & $28,10 \mathrm{~b}$ & $26,32 \mathrm{~b}$ & $25,96 \mathrm{~b}$ \\
D.M+70 & 24,17 & $30,52 \mathrm{a}$ & $33,28 \mathrm{a}$ & $32,63 \mathrm{a}$ & $33,64 \mathrm{a}$ & $35,86 \mathrm{~b}$ & $42,20 \mathrm{a}$ & $44,36 \mathrm{a}$ & $44,93 \mathrm{a}$ & $45,95 \mathrm{a}$ \\
D.M+80 & 10,63 & $6,58 \mathrm{~b}$ & $7,30 \mathrm{~b}$ & $2,26 \mathrm{c}$ & $1,16 \mathrm{c}$ & $0,93 \mathrm{c}$ & $6,30 \mathrm{c}$ & $3,48 \mathrm{c}$ & $1,23 \mathrm{c}$ & $3,13 \mathrm{c}$ \\
D.M+90 & 9,87 & $8,32 \mathrm{~b}$ & $13,21 \mathrm{~b}$ & $12,82 \mathrm{~b}$ & $16,21 \mathrm{c}$ & $24,10 \mathrm{~b}$ & $29,75 \mathrm{~b}$ & $31,91 \mathrm{~b}$ & $30,51 \mathrm{~b}$ & $32,71 \mathrm{~b}$ \\
\hline F-Hitung & $1,10^{\text {th }}$ & $3,47^{*}$ & $5,45^{*}$ & $5,03^{*}$ & $8,05^{*}$ & $9,91^{*}$ & $8,42^{*}$ & $7,24 *$ & $6,57 *$ & $6,18^{*}$ \\
\hline
\end{tabular}

Nilai dalam kolom yang diikuti huruf yang sama, tidak berbeda nyata menurut uji Duncan $\alpha_{0,05}$. HSI: hari setelah infestasi. Kontrol: media PDA tanpa perlakuan. 
Tabel 3. Jumlah spora C. capsici per ml pada 11 hsi

\begin{tabular}{ccc}
\hline Perlakuan & Luas koloni $\left(\mathrm{cm}^{2}\right)$ & Jumlah spora/ml \\
\hline Kontrol & 157,5 & $17,50 \times 10^{6} \mathrm{ab}$ \\
D.M+Aq & 87,18 & $9,33 \times 10^{6} \mathrm{bc}$ \\
D.M+10 & 83,18 & $8,17 \times 10^{6} \mathrm{c}$ \\
D.M+20 & 118,3 & $14,75 \times 10^{6} \mathrm{abc}$ \\
D.M+30 & 23,47 & $2,50 \times 10^{6} \mathrm{c}$ \\
D.M+40 & 92,08 & $10,33 \times 10^{6} \mathrm{abc}$ \\
D.M+50 & 60,87 & $9,83 \times 10^{6} \mathrm{bc}$ \\
D.M+60 & 84,67 & $9,92 \times 10^{6} \mathrm{bc}$ \\
D.M+70 & 47,30 & $9,08 \times 10^{6} \mathrm{bc}$ \\
D.M+80 & 148,3 & $22,67 \times 10^{6} \mathrm{a}$ \\
D.M+90 & 71,08 & $14,75 \times 10^{6} \mathrm{abc}$ \\
\hline
\end{tabular}

Nilai dalam kolom yang diikuti huruf yang sama, tidak berbeda nyata menurut uji Duncan $\alpha_{0,05}$. Hsi: hari setelah infestasi. Kontrol: media PDA tanpa perlakuan.

Hal ini diduga bahwa perlakuan $\mathrm{DM}+10$ dan DM+30 mengandung senyawa yang bersifat antisporulan yang dapat menghambat koloni $C$. capsici dalam memproduksi spora. Namun sebaliknya pada perlakuan DM+80 jumlah spora yang dihasilkan lebih banyak dibandingkan dengan kontrol dan perlakuan lain, hal ini diduga bahwa perlakuan DM+80 mengandung senyawa yang dapat memacu produksi spora $C$. capsici. Adanya senyawa yang terdapat dalam daun mengkudu, misalnya mineral vitamin dan karbohidrat sederhana yang terlarut dapat mendorong pertumbuhan vegetatif $C$. capsici.

\section{KESIMPULAN DAN SARAN}

Dari hasil penelitian yang telah dilakukan dapat disimpulkan bahwa. Fraksi ekstrak daun mengkudu yang terlarut dalam alkohol konsentrasi tertentu berpengaruh terhadap $C$. capsici. Fraksi ekstrak daun mengkudu yang terlarut dalam alkohol konsentrasi $10 \%$, $30 \%, 50 \%, 60 \%, 70 \%, 90 \%$ dan ekstrak daun mengkudu yang terlarut dalam aquades efektif menghambat pertumbuhan diameter pada koloni $C$. capsici, selain menghambat pertumbuhan vegetatif fraksi ekstrak daun mengkudu juga menghambat pembentukan spora (sporulasi) koloni $C$. capsiciyaitu ekstrak daun mengkudu yang terlarut dalam alkohol konsentrasi $10 \%$ dan $30 \%$.

\section{DAFTAR PUSTAKA}

Badan Pusat Statistik. 2011. Tabel Statistik Hortikultura. Diakses di http://bps.go.id. Tanggal 26 Juni 2011.
BPTP Lampung. 2008. Teknologi Budidaya Cabai Merah. Balai Pengkaji Teknologi Pertanian. Bandar Lampung.

Departemen Pertanian. 2011. Basis Data Statistik Pertanian. Diakses di http:// aplikasi.deptan.go.id.Tanggal 15 Juni 2011.

Djauhariya, E., Raharjo, M., dan Ma'un. 2006. Karakterisasi Morfologi dan Mutu Buah Mengkudu. Buletin Plasma Nutfah. 12(1) : 1-8.

Nurmansyah.2010. Efektivitas Minyak Seraiwangi dan Fraksi Sitronellal Terhadap Pertumbuhan Jamur Phytophthora palmivora Penyebab Penyakit Busuk Buah Kakao. Buletin Littro. Kebun Percobaan Laing Solok Balai Ppenelitian Tanaman Obat dan Aromatik. Vol 1 No 1. 43- 52.

Ogundare AO \& Onifade AK. 2009. The Antimicrobial activity of Morinda Lucida leaf extract on Escherichia coli. J. of Medicinal Plants Research 3(4): 319-323.

Pratomo, Aries. 2007. Identifikasi dan Pengendalian Jamur Putih Buah Salak dengan Ekstrak Bunga Kecombrang (Nicolaia speciosa). Laboratorium Pengamatan Hama dan Penyakit.Banyumas.

Prajnanta, F. 2003. Agribisnis Cabai Hibrida. Penebar Swadaya. Jakarta.

Puspita dan Andriani. 2005. Tanaman Obat Keluarga dan Pengobatan Alternatif. Jakarta: Setia Kawan. 
Rukmana, R. 2009. Cabai Hibrida Sistem Mulsa Plastik. Kanisius. Yogyakarta.

Semangun, H. 2004. Penyakit - Penyakit Tanaman Hortikultura di Indonesia. UGM Press. Yogyakarta.
Setiadi. 2000. Bertanam Cabai. Penebar Swadaya. Jakarta. 183.

Sudarmo, S. 2009. Pestisida Nabati Pembuatan dan Pemanfaatannya.Kanisius. Yogyakarta.

Waha, L.G. 2001. Sehat dengan mengkudu. MSF Group, Jakarta. hal. 1 - 44. 